\title{
Non-surgical management of ectopic pregnancy
}

\section{Vineeta Gupta, Shweta Nimonkar*, Priyanka Chaudhari, Namrata Saxena, Parul Singh}

Department of Obstetrics and Gynecology, SG RRIMHS and Shri Mahant Indiresh Hospital, Patel Nagar, Dehradun, Uttarakhand, India

Received: 03 April 2021

Revised: 14 May 2021

Accepted: 15 May 2021

\section{*Correspondence:}

Dr. Shweta Nimonkar,

E-mail: shweta.nimonkar@gmail.com

Copyright: () the author(s), publisher and licensee Medip Academy. This is an open-access article distributed under the terms of the Creative Commons Attribution Non-Commercial License, which permits unrestricted non-commercial use, distribution, and reproduction in any medium, provided the original work is properly cited.

\begin{abstract}
Background: Ectopic pregnancy is a condition when a fertilized ovum is implanted outside the uterine cavity. It is one of the important causes of maternal mortality and morbidity in India. Treatment includes expectant management, medical management and surgical management. Expectant and medical management are the treatment of choice for hemodynamically stable patients who do not want surgical treatment and are desirous of future fertility. The aim of study was to analyse the clinical profile, regimen of medical method used and outcome of non-surgical management in patients with ectopic pregnancy.

Methods: It was a retrospective observational distributive study conducted at Shri Guru Ram Rai Institute of Medical and Health Sciences from January 2015 to December 2019. There were total 182 diagnosed cases of ectopic pregnancy during this duration. Out of them, 87 patients were given non-surgical management. Data was obtained from their medical records to analyse the clinical profile, outcome of expectant and medical management and efficacy of regimen used.

Results: Total 87 patient out of 182 diagnosed cases of ectopic pregnancy were studied. Out of these, $57(65.5 \%)$ patients were in the age group of 20 to 30 years, $44(50.6 \%)$ patients were third gravidas and $32(36.8 \%)$ patients did not have any live issue. Thirty three (37.93\%) patients had haemoglobin less than $10 \mathrm{gm} \%, 41(47.13 \%)$ patients had one or more previous caesarean sections and $73(83.91 \%)$ patients had tubal ectopic pregnancy. Overall success rate with non-surgical management was $94.25 \%$.

Conclusions: Our study emphasised the role of expectant and medical management in stable patients of ectopic pregnancy and recommends to use methotrexate as therapy even when initial serum $\beta$ HCG levels are more than 5000 IU and haemoglobin level less than 10 gm $\%$ under close monitoring.
\end{abstract}

Keywords: Ectopic pregnancy, Medical management, Methotrexate

\section{INTRODUCTION}

Ectopic pregnancy is a potentially life threatening condition occurring in 1-2\% of all pregnancies. The most common ectopic implantation site is the fallopian tube while only $10 \%$ of ectopic pregnancy implant in the cervix, ovary, myometrium, interstitial portion of the fallopian tube, abdominal cavity or within a caesarean section scar. There is global rise in number of ectopic pregnancies over past few decades because of increased prevalence of sexually transmitted tubal infections, early diagnosis with sensitive assay for chorionic gonadotropin and transvaginal ultrasound, induced abortion followed by infections, tubal surgeries and increased use of assisted reproductive techniques. ${ }^{1}$ High index of suspicion specially in females of reproductive age group presenting with abdominal pain and vaginal bleeding should be used and these females should be screened for pregnancy regardless of the contraception they are using. 
Treatment methods include expectant management, medical management and surgical management. Traditionally the treatment of ectopic pregnancy was limited to surgery but from mid 1980s medical management with methotrexate became available for selected patients which revolutionized the management of ectopic pregnancies. Medical management of ectopic pregnancy is preferred over surgical procedures as they save patient from undergoing morbidity associated with surgery, effects of anaesthesia, potentially less tubal damage, less cost, comparatively less need of hospitalization. $^{2}$ Medical management is desired in patients who want to keep their fertility options open. Medical management with methotrexate can be considered for women with a confirmed or high clinical suspicion of ectopic pregnancy who are hemodynamically stable, with an unruptured mass, and no absolute contraindication to methotrexate therapy. Relative contraindications are unruptured mass $>3.5 \mathrm{~cm}$, fetal cardiac activity and a quantitative serum $\beta$ HCG level between 6000-15000 $\mathrm{mIU} / \mathrm{ml}^{2}$ Aim of our study is to understand and analyse the clinical profile of ectopic pregnancies, regimen used and outcome of medical management.

\section{METHODS}

Our study was a retrospective study conducted at Shri Guru Ram Rai Institute of Medical and Health Sciences Dehradun which is a tertiary care centre in Uttarakhand. Data from January 2015 to December 2019 was analysed.

\section{Inclusion criteria}

All patients who were given non-surgical management for ectopic pregnancy as per the Institutional protocol during this time period were included in the study. Data regarding age, parity, risk factors, presenting complaints, period of amenorrhea, complications, serum $\beta$ HCG levels, ultrasound findings, medical management, dose, regimen and outcome of treatment, number of days of stay required etc. was recorded.

\section{Exclusion criteria}

Exclusion criteria were patients with acute ruptured ectopic pregnancy who were hemodynamically unstable, chronic ectopic pregnancy, patients with hepatic and renal dysfunction. Pregnancy of unknown location or late presentation of incomplete abortions in which no intrauterine gestation sac was seen were also excluded.

All the patients were hospitalised during the medical management. All patients were counselled and detailed informed written consent was taken regarding the practical outcome of expectant or medical management, risk of requirement of emergency laparotomy, failure of treatment and potential side effects of methotrexate therapy. Blood transfusion and parenteral iron therapy was given as per requirement. Patients who had initial serum beta HCG less than $1000 \mathrm{mIU} / \mathrm{ml}$ were given expectant management, those with more than $1000 \mathrm{mIU} / \mathrm{ml}$ were given medical management with injection methotrexate. In case of suboptimal fall or rise in serum $\beta$ HCG levels in patients on expectant management, medical management was started. Protocol of medical management was a single dose of injection methotrexate (MTX) $50 \mathrm{mg}$ i.m. or $1 \mathrm{mg} / \mathrm{kg}$ body weight when body weight was less than $50 \mathrm{~kg}$. A repeat serum $\beta$ HCG level was done on $4^{\text {th }}$ day. If the levels dropped by $15 \%$ then patient was reviewed weekly till serum $\beta$ HCG was $<5 \mathrm{mIU} / \mathrm{ml}$. Those patients with less than $15 \%$ decline after 4 days were given multiple doses of injection methotrexate $50 \mathrm{mg}$ with injection folinic acid on alternate days for total 4 doses each. Patients were again followed up after 4 days. Patients were instructed to refrain from intercourse and heavy activities until complete resolution of the ectopic pregnancy as was seen by normalization of serum $\beta$ HCG levels. A follow-up Ultrasound was done after 1 month or later. Statistical analysis of the data was performed by using SPSS-23 version. According to Chi-square method, $\mathrm{p}$ value $<0.05$ was considered to be significant.

\section{RESULTS}

During the study period of five years from January 2015 to December 2019 there were total 182 diagnosed cases of ectopic pregnancy out of them 95 (52.2\%) underwent surgical treatment (Figure 1). Out of these $88(92.63 \%)$ had tubal pregnancy, $5(5.26 \%)$ ovarian and $2(2.10 \%)$ had caesarean scar pregnancy. Sixty four $(67.36 \%)$ of these patients had laparotomy while $31(32.63 \%)$ patients had laparoscopic management. Eighty seven (47.8\%) patients who were included in the study were given non-surgical management either expectant, methotrexate by single dose or multiple dose or intra sac injection of methotrexate. Study found that all patients who were given non-surgical treatment were hemodynamically stable, normotensive with no tachycardia, no abdominal distension suggestive of significant abdominal collection of blood. All patients were kept hospitalized for close monitoring with multipara monitors.

Our study showed that maximum $57(65.5 \%)$ patients were in the age group of 20-30 years followed by 28 (32.18\%) in age group of more than 30 years (Table 1). There were $44(50.57 \%)$ third gravidas, $25(28.7 \%)$ were second gravidas and $18(20.7 \%)$ were primigravidas. As even third gravidas may not have single live child hence more useful data was number of live children in the family. And our study found that $32(36.8 \%)$ patients had no living child while $26(29.9 \%)$ had one and $29(33.3 \%)$ had two or more living children. Sixty-four $(73.56 \%)$ patients were housewives while $23(26.4 \%)$ patients were working females. 


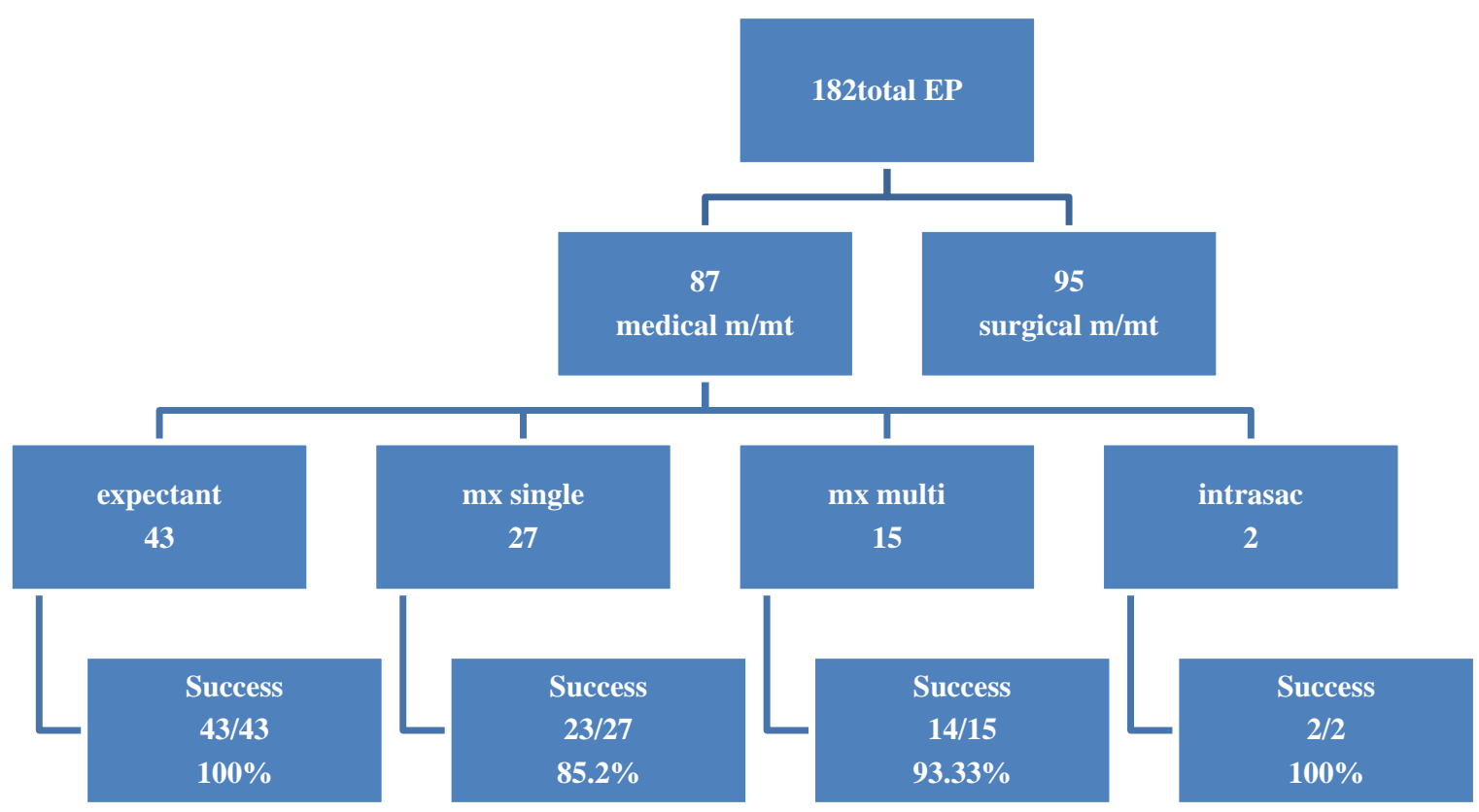

Figure 1: Management-wise distribution of patients.

Table 1: Demographic characteristics of patients.

\begin{tabular}{|lll|}
\hline Variables & N & Percentage \\
\hline Age & & \\
\hline$<20$ years & 02 & 2.3 \\
\hline 20-30 years & 57 & 65.51 \\
\hline$>30$ years & 28 & 32.18 \\
\hline Gravida & & \\
\hline 1 & 18 & 20.7 \\
\hline 2 & 25 & 28.7 \\
\hline$\geq 3$ & 44 & 50.57 \\
\hline Live children & & \\
\hline None alive & 32 & 36.8 \\
\hline 1 & 26 & 29.9 \\
\hline$\geq 2$ & 29 & 33.3 \\
\hline Occupation & & \\
\hline Housewife & 64 & 73.56 \\
\hline Working & 23 & 26.44 \\
\hline
\end{tabular}

Table 2: Risk factors and location.

\begin{tabular}{|lll|}
\hline Risk factors & N & Percentage \\
\hline Previous caesarean sections & 41 & 47.13 \\
\hline Previous abortions & 22 & 25.29 \\
\hline Medical abortion pills & 12 & 14.94 \\
\hline Tubal surgeries & 08 & 9.2 \\
\hline Infertility & 08 & 9.2 \\
\hline Previous D and E & 07 & 8.05 \\
\hline Previous ectopic pregnancy & 07 & 8.05 \\
\hline Koch's & 04 & 4.6 \\
\hline Endometriosis & 01 & 1.15 \\
\hline Location & & \\
\hline Tubal pregnancy & 75 & 85.21 \\
\hline Caesarean scar pregnancy & 12 & 13.79 \\
\hline
\end{tabular}

As seen in Table 2, in our study we found that the associated risk factors were present in many patients and many of them had multiple risk factors. Forty-one $(47.13 \%)$ patients had one or more previous caesarean section, $22(25.29 \%)$ patients had previous history of abortions and $\mathrm{D}$ and $\mathrm{C}$.

Twelve (14.9\%) patients presented after intake of unsupervised medical abortion pills which are freely available over the counter in India. History of infertility and its treatment was seen in $8(9.2 \%)$ patients and similar number had history of tubal surgeries. Seven (8.2\%) patients had past history of ectopic pregnancy. Majority i.e. $75(86.21 \%)$ patients had tubal pregnancy while 12 $(13.79 \%)$ cases of scar ectopic pregnancy treated by medical management were also included.

Table 3 shows that $42(48.27 \%)$ patients had serum $\beta$ HCG level less than $1000 \mathrm{mIU} / \mathrm{ml}$ and out of them $32(76.2 \%)$ were given expectant management. Ten $(23.8 \%)$ patients were given medical management with methotrexate as the repeat serum $\beta$ HCG after 48 hours had a rising trend. Seven patients $(16.67 \%)$ required single dose methotrexate injection and $3(7.14 \%)$ required multiple doses of injection methotrexate as in them decline in serum $\beta$ HCG level was not adequate. Out of $24(27.59 \%)$ patients with serum $\beta$ HCG between 1000-5000 mIU/ml, 10 (41.67\%) were treated expectantly $11(45.83 \%)$ by single dose methotrexate and $3(12.5 \%)$ by multiple doses of methotrexate. Out of $10(11.5 \%)$ patients with serum $\beta$ HCG between 5000-10,000 mIU/ml, $1(10 \%)$ was treated expectantly, $3(30 \%)$ by single dose methotrexate and 5 $(50 \%)$ by multiple doses of methotrexate. In one $(10 \%)$ patient, intrasac injection of methotrexate was given. 
Some patients in whom initial serum $\beta$ HCG levels were more than $1000 \mathrm{mIU} / \mathrm{ml}$ were treated expectantly as in them the repeat serum $\beta$ HCG had a decreasing trend, In $11(12.65 \%)$ patients, in whom serum $\beta$ HCG level was more than $10,000 \mathrm{mIU} / \mathrm{ml}, 6(54.55 \%)$ patients were managed by single dose and $4(36.66 \%)$ by multiple doses of injection methotrexate. Out of these 11 patients with serum $\beta$ HCG levels more than $10,000 \mathrm{mIU} / \mathrm{ml}, 10$ $(90.9 \%)$ were patients having caesarean scar pregnancy. In one $(9.09 \%)$ patient, intrasac injection of methotrexate was given.

Overall success rate of non-surgical management in our study was $94.25 \%$. In patients with serum $\beta$ HCG levels less than $1000 \mathrm{mIU} / \mathrm{ml}$, success rate was $100 \%$, in levels between $1000-5000 \mathrm{mIU} / \mathrm{ml}$, it was $91.67 \%$, in levels between 5000 to 10,000 , it was $80 \%$ while in levels above $10,000 \mathrm{mIU} / \mathrm{ml}$, it was $90.91 \%$. Correlation between serum $\beta$ HCG levels and success rate was calculated by
Chi square test (Chi square statistic 31.9984). It was found to be statistically significant ( $\mathrm{p}$ value $<0.00001$ ). Better success rate in patients with serum $\beta$ HCG levels above $10,000 \mathrm{mIU} / \mathrm{ml}$ in our study maybe because 10 out of 11 $(90.9 \%)$ of these patients had caesarean scar pregnancy in whom initial serum $\beta$ HCG levels are higher as compared to tubal pregnancy.

We found in $4(14.81 \%)$ cases of Single dose injection methotrexate and $1(6.67 \%)$ case of multiple doses of injection methotrexate, medical management was not successful and patient required surgery. Out of these, in patients treated with single dose Methotrexate therapy, 2 failures had initial serum $\beta$ HCG levels between 1000$5000 \mathrm{mIU} / \mathrm{ml}$ while levels between $5000-10000 \mathrm{mIU} / \mathrm{ml}$ and $>10000 \mathrm{mIU} / \mathrm{ml}$ had one failure in each group. With multiple dose therapy, one patient had failed medical management at serum $\beta \mathrm{HCG}$ of $8227 \mathrm{mIU} / \mathrm{ml}$.

Table 3: Correlation of serum $\beta$ HCG and $\mathrm{Hb} \%$ levels with success rate.

\begin{tabular}{|c|c|c|c|c|c|c|c|c|}
\hline $\begin{array}{l}\text { S. } \beta \text { HCG } \\
(\mathrm{mIU} / \mathrm{ml})\end{array}$ & $\mathbf{N}(\%)$ & $\begin{array}{l}\text { Mean } \\
\text { Hb\% }\end{array}$ & Expectant & $\begin{array}{c}\text { MTX } \\
\text { (single) }\end{array}$ & $\begin{array}{c}\text { MTX } \\
\text { (multiple) }\end{array}$ & Intrasac & Failed & $\begin{array}{l}\text { Success- } \\
\text { rate* }\end{array}$ \\
\hline$<1000$ & $42(48.27)$ & 10.97 & $32(76.1 \%)$ & 07 (16.67\%) & $03(7.14 \%)$ & & 0 & $100 \%$ \\
\hline 1000-5000 & $24(27.59)$ & 10.50 & $10(41.67 \%)$ & $11(45.83 \%)$ & $03(12.5 \%)$ & & $2(8.33 \%)$ & $91.67 \%$ \\
\hline $5000-10000$ & $10(11.5)$ & 10.72 & $01(10 \%)$ & $03(30 \%)$ & $05(50 \%)$ & $01(10 \%)$ & $2(20 \%)$ & $80 \%$ \\
\hline$>10000$ & $11(12.6)$ & 10.53 & & $06(54.55 \%)$ & $04(36.66 \%)$ & $01(9.09 \%)$ & $1(9.09 \%)$ & $90.91 \%$ \\
\hline Success & & & $43 / 43$ & $23 / 27$ & $14 / 15$ & $2 / 2$ & & \\
\hline Percentage & & & $100 \%$ & $85.2 \%$ & $93.33 \%$ & $100 \%$ & & \\
\hline \multicolumn{9}{|l|}{$\mathrm{Hb}(\mathrm{gm} \%)$} \\
\hline$>10$ & $54(62.07)$ & & $30(55.56 \%)$ & $13(24.07 \%)$ & $09(16.67 \%)$ & $02(3.7 \%)$ & $3(5.55 \%)$ & $94.45 \%$ \\
\hline $7-10$ & $28(32.18)$ & & $10(35.715)$ & $13(46.43 \%)$ & $05(17.86 \%)$ & & $2(7.14 \%)$ & $92.86 \%$ \\
\hline $5-7$ & $05(5.75)$ & & $03(60 \%)$ & $01(20 \%)$ & $01(20 \%)$ & & 0 & $100 \%$ \\
\hline
\end{tabular}

*Chi square statistic is 31.9984 (p value $<0.00001$, statistically significant).

Table 4: Correlation of serum $\beta$ HCG with $\mathrm{Hb} \%$ levels.

\begin{tabular}{|llll|}
\hline $\mathrm{S} \boldsymbol{\beta}$ HCG $(\mathrm{mIU} / \mathrm{ml})$ & $\mathbf{5 - 7} \mathrm{gm} \%$ & $\mathbf{7 - 1 0} \mathbf{g m} \%$ & $>\mathbf{1 0} \mathbf{g m} \%$ \\
\hline $\mathbf{1 0 0 0}$ & - & 12 & 30 \\
\hline $\mathbf{1 0 0 0 - 5 0 0 0}$ & 2 & 10 & 15 \\
\hline $\mathbf{5 0 0 0 - 1 0 0 0 0}$ & 1 & 05 & 05 \\
\hline$>\mathbf{1 0 0 0 0}$ & 2 & 01 & 04 \\
\hline
\end{tabular}

Chi square statistic is 9.4607 ( $\mathrm{p}$ value $=0.05056$, statistically not significant).

As seen in Table 4, fifty four $(62.07 \%)$ patients who received treatment had hemoglobin levels more than 10 gm\%, 28 (32.18\%) had $\mathrm{Hb}$ between 7-10 gm\%. But 5 (5.75\%) patients had $\mathrm{Hb}$ level less than $7 \mathrm{gm} \%$ who were managed by non-surgical treatment successfully. They remained hemodynamically stable during the course of treatment. Nine patients out of eighty seven (10.3\%) who were managed medically had Haemoglobin less than 10 gm $\%$ and serum $\beta$ HCG more than 5000 IU. We had 2 $(6.06 \%)$ failures in patients with haemoglobin less than 10 gm\%. A correlation of serum $\beta \mathrm{HCG}$ and $\mathrm{Hb} \%$ was also done which is shown in Table 4. Correlation of serum $\beta$ HCG and hemoglobin was evaluated, by Chi square test and $\mathrm{p}$ value was 0.05056 which was not statistically significant. There were no complications or drug related side-effects in our study.

\section{DISCUSSION}

Ectopic pregnancy remains a dreaded diagnosis among obstetrician due to its potentially catastrophic outcomes. Treatment whether surgical or medical is always guided by the hemodynamic state of patient, initial serum $\beta$ HCG levels, ultrasound findings, symptomatology and presence of hemoperitoneum. With better diagnostic facilities and awareness patients are presenting to us early providing a window to offer medical or expectant management quite frequently. Conservative management of ectopic 
pregnancy is desired by patients as it saves their future fertility options, it is economical, prevents the stress of surgery and prolonged hospital stay. Methotrexate has revolutionized the management of ectopic pregnancy and several studies have by now established its role. Embryonic cardiac activity, high initial HCG concentration, ectopic pregnancy more than $4 \mathrm{~cm}$ in size, refusal to accept blood transfusions are some relative contraindications for methotrexate therapy. ${ }^{3}$

As a rule we admit all patients of diagnosed ectopic pregnancy. All hemodynamically unstable patients are immediately taken up for surgery. Those who are hemodynamically stable are further evaluated by Ultrasound to assess sac size, hemoperitonum, location, cardiac activity and laboratory reports of serum beta HCG, hemoglobin, renal and liver function tests. We offered medical management to all those patients who were hemodynamically and symptoms wise stable. Patients with low haemoglobin and those with fluid in peritoneal cavity but no gross abdominal distensions were also offered medical management after a well informed consent explaining the requirement of emergency surgery in case patient starts showing any signs of instability.

A systematic review has shown a failure of $14.3 \%$ or higher with methotrexate when pre treatment HCG levels are higher than $5000 \mathrm{mIU} / \mathrm{ml}$ compared with $3.7 \%$ when levels are less than $5000 \mathrm{mIU} / \mathrm{ml}^{4}{ }^{4} \mathrm{We}$ had an overall success rate of $94.25 \%$. Twenty one $(24.13 \%)$ patients in our study were given medical treatment with initial HCG levels more than $5000 \mathrm{mIU} / \mathrm{ml}$. On levels more than 5000 $\mathrm{mIU} / \mathrm{ml}$ we had 3 failures i.e. $14.3 \%$ while $3 \%$ (2 out of 66) had failure with treatment when HCG levels were less than $5000 \mathrm{mIU} / \mathrm{ml}$. Correlation between serum $\beta$ HCG levels and success rate was found to be statistically significant in our study. Our success rate was maximum in patients on expectant management $(100 \%)$, followed by $91.67 \%$ in patients with serum $\beta$ HCG levels between 1000 to $5000 \mathrm{mIU} / \mathrm{ml}$ and $80 \%$ in patients with serum $\beta$ HCG levels between 5000 to $10,000 \mathrm{mIU} / \mathrm{ml}$. Various similar studies documented overall success rates of medical management between $75 \%$ by Vaswani, $78.5 \%$ (314/400) by Bonin et al, $77.1 \%(285 / 370)$ by Mirbolouk et al and $94 \%$ by Juneja et al. ${ }^{5-8}$

Our success rate in patients with serum $\beta$ HCG levels more than $10,000 \mathrm{mIU} / \mathrm{ml}$ was $90.91 \%$. Ten $(90.91 \%)$ of these patients had caesarean scar pregnancy who were all successfully treated by methotrexate. One $(9.09 \%)$ patient had failure. She was a primigravida who was very keen for medical management in spite of counselling. Higher success rate in these patients maybe because of better response to medical management in women with caesarean scar pregnancy even with higher levels of serum $\beta$ HCG levels. Peng et al reported $67.3 \%$ success rate with systemic methotrexate and $69.2 \%$ with local methotrexate in caesarean scar pregnancy while Semih et al reported it to be $100 \%$ with systemic as well as local methotrexate administration with mean pre treatment serum $\beta$ HCG levels $7606 \mathrm{mIU} / \mathrm{ml}$ and 27,970mIU/ $\mathrm{ml}$ respectively. ${ }^{9,10}$

The presence of free intraperitoneal fluid in EP-diagnosed patients is crucial for treatment planning and evaluation. It has been described as a relative contraindication for MTX regimens in the early years of the use of MTX for EP management. Currently, it does not constitute a contraindication for MTX regimens unless there is haemodynamic instability. ${ }^{3}$ Our study further proves that the amount of free intraperitoneal fluid should be disregarded as a contraindication for medical management.

In our study, $37.93 \%$ patients received medical management with initial $\mathrm{Hb} \%$ of less than $10 \mathrm{gm} \%$ but were hemodynamically stable and had no significant hemoperitoneum. We had $2(6.06 \%)$ failures in patients with haemoglobin less than $10 \mathrm{gm} \%$ both of these had serum $\beta$ HCG levels less than $5000 \mathrm{mIU} / \mathrm{ml}$ further proving that success does not depend on haemoglobin.

Moreover, haemoglobin and serum $\beta$ HCG levels do not have any correlation in determining success. This is an important and encouraging data as sometimes clinicians are biased towards surgical approach in such anemic patients thinking of an ongoing pelvic bleed from ectopic site. As many of our patients were preconceptionally anemic, instead of $\mathrm{Hb} \%$ levels, the overall condition of patient, fall in $\mathrm{Hb} \%$, and the results of diagnostic modalities should guide our treatment.

There are some limitations of our study. We need more studies and data to establish expectant or medical management in patients with anemia and serum $\beta$ HCG more than $5000 \mathrm{mIU} / \mathrm{ml}$. Our $10.3 \%$ (9 out of 87 ) such patients were successfully managed but we couldn't find similar studies to compare our results.

\section{CONCLUSION}

Non-surgical management of ectopic pregnancy is a safe option with good success rate even in anemic women with initial serum $\beta$ HCG levels more than $5000 \mathrm{mIU} / \mathrm{ml}$ provided they are hemodynamically stable.

The criteria for non-surgical management may be revised as the most important factor is hemodynamic stability rather than haemoglobin and serum $\beta$ HCG levels.

Patients need to be closely monitored and kept under observation during the treatment especially to those who are given medical management out of the widely used criteria.

\author{
Funding: No funding sources \\ Conflict of interest: None declared \\ Ethical approval: The study was approved by the \\ Institutional Ethics Committee
}




\section{REFERENCES}

1. Cunningham FG, Gant NF, Leveno KJ, Gilstrap LC, Hauth JC, Wenstrom KD. Ectopic pregnancy. In: Cunningham FG, Gant NF, Leveno KJ, Gilstrap LC, Hauth JC, Wenstrom KD eds. Williams Obstetrics. 21st edn. USA: Mc Graw Hill Companies; 2001:883910.

2. ACOG Practice Bulletin No. 94: Medical management of ectopic pregnancy. Obstet Gynecol. 2008;111:1479-85.

3. Practice Committee of the American Society for Reproductive Medicine. Medical treatment of ectopic pregnancy: a committee opinion. Fertil Steril. 2013;100:638-44.

4. Menon S, Colins J, Barnhart KT. Establishing a human chorionic gonadotropins cutoff to guide methotrexate treatment of ectopic pregnancy: a systematic review. Fertil Steril. 2007;87:481-4.

5. Vaswani PR. Predictors of success of medical management of ectopic pregnancy in a tertiary care Hospital in United Arab Emirates. J Clin Diagn Res. 2014;8(8): OCO4-8.

6. Bonin L, Pedreiro C, Moret S, Chene G, Gaucherand P, Lamblin G. Predictive factors for the methotrexate treatment outcome in ectopic pregnancy: a comparative study of 400 cases. Eur J Obstet Gynecol Reprod Biol. 2017;208:23-30.
7. Mirbolouk F, Yousefneznad A, Ghanbari A. Predicting factors of medical treatment success with single dose methotrexate in tubal ectopic pregnancy: a retrospective study. Iran $\mathrm{J}$ Reprod Med. 2015;13(6):351-4.

8. Juneja SK, Jain K. Success of medical management of tubal ectopic pregnancy with Methotrexate in a tertiary hospital in North India Int $\mathrm{J}$ Reprod Contracept Obstet Gynecol. 2018;7(6):2377-80.

9. Peng P, Gui T, Liu X, Chen W, Liu Z. Comparative efficacy and safety of local and systemic methotrexate injection in caesarean scar pregnancy. Therap Clin Risk Manag. 2015;11:137-42.

10. Uludag SZ, Kutuk MS, Ak M, Ozgun MT, Dolanbay M, Aygen EM, et al. Comparison of systemic and local methotrexate treatments in cesarean scar pregnancies: time to change conventional treatment and follow-up protocols. Eur J Obstet Gynecol Reprod Biol. 2016;206:131-5.

Cite this article as: Gupta V, Nimonkar S, Chaudhari P, Saxena N, Singh P. Non-surgical management of ectopic pregnancy. Int J Reprod Contracept Obstet Gynecol 2021;10:2686-91. 